\title{
Assessing availability and greenhouse gas emissions of lignocellulosic biomass feedstock supply - case study for a catchment in England
}

\author{
Yuanzhi Ni, Onesmus N. Mwabonje, Goetz M. Richter, Aiming Qi, Kenny Yeung, Martin \\ Patel and Jeremy Woods
}

\author{
Yuanzhi Ni, Imperial College London, Center for Environmental Policy \\ Mwabonje, Onesmus N, Imperial College London, Center for Environmental Policy \\ Richter, Goetz, Rothamsted Research, Sustainable Soils \& Grassland Systems \\ Qi, Aiming, University of Hertfordshire, Department of Biological and Environmental Sciences, \\ Yeung, Kenny, LCAworks Limited, LCA department \\ Patel, Martin, University of Geneva, Institute of Environmental Science \\ Woods, Jeremy, Imperial College London, Centre for Environmental Policy
}

\section{ABSTRACT:}

Feedstocks from lignocellulosic biomass (LCB) include crop residues and dedicated perennial biomass crops, of which the latter are often considered superior in terms of climate change mitigation potential. Uncertainty remains over their availability as feedstocks for biomass provision and the net greenhouse gas emissions (GHG) during crop production. Our objective was to assess the optimal land allocation to wheat and Miscanthus in a specific case study located in England, in order to increase biomass availability, improve the carbon balance (and reduce the consequent GHG emissions), minimally constrain grain production losses from wheat. Using soil and climate variables for a catchment in East England, biomass yields and direct soil nitrogen emissions were simulated with validated process-based models. A 'Field to up-stream factory gate' Life Cycle Assessment was conducted to estimate indirect management-related GHG emissions. Results show that feedstock supply from wheat straw can be beneficially supplemented with LCB from Miscanthus grown on selected low quality soils. In our study, $8 \%$ of the less productive arable land area was dedicated to Miscanthus, increasing total LCB provision by about $150 \%$, with a $52 \%$ reduction in GHG emission per ton LCB delivered and only a minor effect on wheat grain production (-3\%). In conclusion, even without considering the likely carbon sequestration in impoverished soils, agriculture 
should embrace the opportunities of providing the bioeconomy with LCB from dedicated, perennial crops.

Keywords: lignocellulosic biomass, greenhouse gases (GHG), Miscanthus, wheat straw, feedstock supply, STAMINA, DNDC

(1)

\section{INTRODUCTION}

With the potential benefits in climate change mitigation, development of rural economy, energy security and reducing fossil fuel dependency, biomass crops have attracted interest in both bioenergy and biomaterial production. At present 'first generation' biomass (1GB) has been the major feedstock and technology deployed in national bio-economy strategies. However, concerns about competition for food, land use change, loss of biodiversity and raised $\mathrm{GHG}$ emissions ${ }^{1}$ have led to an increased focus on the utilization of lignocellulosic biomass (LCB), resourced from agricultural and forestry residues and dedicated biomass crops.

The drivers for LCB feedstocks include mainly their higher Energy Return On Investment ${ }^{2}$, and better environmental and social performance than 1GB in the sustainability assessment. However, there are concerns regarding the actual provisioning capacity of LCB, especially from agricultural residues such as cereal straw. Although there have been many attempts to calculate this potential ${ }^{3-6}$, it remains difficult to quantify ${ }^{7}$. Most estimates of straw production are based on measurements of grain production and assuming a constant relationship between grain and straw yield ${ }^{5}$. Cereal straw production is concentrated in the arable eastern parts of England; around 70\% of UK wheat straw is produced in the Yorkshire and Humber region, East Midlands, East Anglia and the Southeast regions ${ }^{6}$. In the UK, straw 
is mainly used for animal bedding, horticulture and bioenergy $y^{8}$, with $32 \%$ to $39 \%$ being incorporated back to the soil to maintain the soil organic carbon (SOC) content ${ }^{4}$. Only approximate 300 to $487 \mathrm{kt} /$ year (2-4\% of total produced cereal and oilseed rape straw) was used for bioenergy generation ${ }^{6}$. There are no robust official survey data available for straw usage in animal bedding; estimates range between 5.8 Mt and 6.24 Mt annually for all cereal and oilseed rape straw, based on livestock statistics from Defra (Department of Environment, Food and Rural Affairs) $)^{6,8}$. Current straw use is shown in Fig. 1 based on a wide range of literature ${ }^{4,6,8}$.

Dedicated biomass crops have the advantage that they can be grown on marginal arable land $^{9,10}$. However, the actual land area needed to produce the specified amount of biomass could be higher due to lower and variable local productivity ${ }^{11}$. Currently, one of the main challenges for lignocellulosic bioenergy or biomaterial production is that the high overall production cost is dominated by pretreatment costs of LCB feedstock ${ }^{12}$. The overall production cost could be aggravated when the feedstock prices increase due to emerging competition for biomass across the sub-sectors of bio-economy (bioenergy, biomaterial and traditional uses, such as animal feed and bedding etc.) $)^{12,13,14}$.

\section{Figure 1.}

Most research on biogeochemical impacts of Miscanthus are conducted on silt clay loam soil ${ }^{15-19}$. However, it is less likely that those soils could be converted to Miscanthus production, due to farmers' unwillingness to change, especially on soils where they generally achieve good yields for conventional arable crops. Understanding the performance of Miscanthus on a wider range of soil types, especially on sandy soils which have low cereal yields but high nitrogen $(\mathrm{N}) \operatorname{losses}^{20}$ is important to identify the suitable locations for Miscanthus production. Compared to wheat, higher yields of Miscanthus with lower N 
inputs and losses per unit of production are likely to reduce Greenhouse Gas (GHG) emissions of biomass production and lower its environmental footprint and costs.

Accurate estimates of GHG emissions and resource use efficiencies are important in understanding and determining the sustainability of bioenergy and bio-based chemicals. Full Life Cycle Assessment (LCA) for biorefinery chains are often constrained by the lack of sufficiently detailed and site-specific information on the pre-harvest GHG balance related to agricultural management, especially $\mathrm{N}_{2} \mathrm{O}$ emissions from $\mathrm{N}$ fertiliser application, as an important source of $\mathrm{GHG}^{21}$. The IPCC Tier 1 method provides a default estimate of $\mathrm{N}_{2} \mathrm{O}$ emissions from agriculture for both, direct and indirect emissions, based on $\mathrm{N}$ fertiliser inputs, but ignores other important crop management, soil and atmospheric variables. The Tier 3 approach suggests the use of process-based biogeochemical models to achieve more accurate site-specific estimates of the GHG flux from variable agricultural systems ${ }^{22}$. A number of studies have integrated process-based model generated $\mathrm{N}_{2} \mathrm{O}$ emission results into $\mathrm{LCA}^{21,23,24}$. However, most of this work has been carried out solely for conventional crops (first generation biomass) ${ }^{21,23}$. Very limited work can be found for simulating the pre-harvest $\mathrm{N}_{2} \mathrm{O}$ emission for perennial energy crops such as Miscanthus based on process-based models, due to the limited availability of such models developed for dedicated LCB crops integrated into arable cropping systems. To address this gap, process-based models STAMINA (Stability and Mitigation of Arable Systems in Hilly Landscapes) ${ }^{25}$ and carbonnitrogen $(\mathrm{C}, \mathrm{N})$ turnover model DNDC (i.e. DeNitrification-DeComposition) ${ }^{26}$ were used for Tier 3 approaches to estimate dry matter yields (DMYs) and the $\mathrm{N}$ emissions of winter wheat and Miscanthus.

The overall objective of this paper is to estimate the impacts and benefits of moving from an 'arable only' to a proposed 'mixed (arable and perennial)' feedstock provision scenario. 
1 We assessed the potential of local LCB provisioning capacity, and the resulting GHG emissions under different supply scenarios, whilst exploring the potential impacts arising from integrating Miscanthus into a wheat production system in eastern England.

\section{MATERIAL AND METHODS}

The crop growth model system STAMINA ${ }^{25}$ and C-N turnover model DNDC ${ }^{26}$ were calibrated to estimate DMY data only, considering both, winter wheat and Miscanthus. No model evaluation could be done for $\mathrm{N}_{2} \mathrm{O}$ emission and $\mathrm{NO}_{3}{ }^{-}$leaching arising from their supply due to lack of experimental data. They were up-scaled to the catchment to estimate the LCB supply capacity and GHG balance of production in a rural area nearby the city of Hull in England (max. $50 \mathrm{~km}$ as feedstock transport distance from farm to conversion plant; Fig. 2). The catchment consists of parts of the Yorkshire \& Humber and East Midlands regions, major wheat production areas in England.

Firstly, crop growth parameters for both, the STAMINA and DNDC models were calibrated based on literature and evaluated against observations on farms across England. Three indicators, including coefficient of determination $\left(\mathrm{R}^{2}\right)$, root mean square error (RMSE) and relative mean absolute bias error expressed as a percentage (MBE\%) were calculated to assess the goodness-of-fit between model simulated and measured yields of both crops. Secondly, $\mathrm{LCB}$ availability, $\mathrm{NO}_{3}{ }^{-}$leaching and $\mathrm{N}_{2} \mathrm{O}$ emissions were simulated for both, 'arable only' and proposed 'mixed arable-perennial' feedstock supply scenarios. For the latter, Miscanthus was assumed to replace wheat on selected low-quality soils, which are coarse textured, less productive and have the highest $\mathrm{NO}_{3}^{-}$leaching/wheat grain production ratio (kgN/t Grain) based on modelled results. These represent $8 \%$ of the total catchment area. Thirdly, the GHG balance results were combined with a 'field to up-stream factory gate' LCA to compare the global warming potential (GWP) associated with different 
$1 \quad$ lignocellulosic feedstock supply scenarios.

2

Figure 2

\subsection{Process-based models}

The STAMINA modelling system simulates micro-meteorology, hydrology, crop development and growth, integrating spatial information on soil and topography for a range of crops, including both arable crops (winter wheat, maize, potato, barley etc.) and perennial crops (Miscanthus, willow, switchgrass etc.). The STAMINA-winter wheat model is described in detail elsewhere ${ }^{27}$. In this work, the catchment region is represented as a matrix of $1 \mathrm{~km}^{2}$ cells, within which all important variables of soil, climate, crop and crop management are assumed to be homogeneous. STAMINA-winter wheat model had been calibrated against winter wheat yields observed in Bedfordshire (England) ${ }^{27}$. Here, three sets of UK weather, soil and on-farm measured yield data from an earlier study ${ }^{28}$ (Table 1) were used for model evaluation. DMYs were simulated with an acceptable accuracy (Fig. 3), RMSE of $1.36 \mathrm{t} / \mathrm{ha}$ and MBE\% of $12 \%$. The STAMINA-BeGRAS Model is a sink-source interaction model based on the principles described in LINGRA for small grasses ${ }^{29}$ and was expanded for the allocation of biomass to belowground biomass (rhizomes and roots). BeGRAS model was implemented in the STAMINA modelling system ${ }^{30}$ and calibrated for Miscanthus using detailed data collected at Rothamsted Research. In this simulation work for Miscanthus, weather, soil and on-farm measured yield data (Table 1) from the Rothamsted 408 trial $^{31}$ are used for model evaluation. The RMSE between measured and simulated yields is $1.58 \mathrm{t} / \mathrm{ha}$ and $\mathrm{MBE} \%$ is $12 \%$ (Fig. 3). The BeGraS model simulated Miscanthus DMYs at harvest ( $1^{\text {st }}$ to $3^{\text {rd }}$ March) after two establishment years, for 13 years of harvest. The RMSE between measured and simulated yields was $1.58 \mathrm{t} / \mathrm{ha}$ and MBE\% is 

12\% (Fig. 3). 30-year average scenario yields (two 15-year growing cycles) were generated for each soil type to be used in the overall assessment.

DNDC model was originally designed to simulate $\mathrm{C}$ and $\mathrm{N}$ biogeochemical cycles occurring in agricultural systems at regional scales in the U.S. ${ }^{32}$ and was further extended to cover a wider range of countries and districts and other ecosystems ${ }^{33,34}$. DNDC is capable of predicting the main GHGs fluxes from soil $\left(\mathrm{N}_{2} \mathrm{O}, \mathrm{CO}_{2}\right.$ and $\left.\mathrm{CH}_{4}\right)$ and other key environmental and economic indicators, including crop yields, ammonia $\left(\mathrm{NH}_{3}\right)$ volatilization and nitrate $\left(\mathrm{NO}_{3}^{-}\right)$leaching rates and quantities ${ }^{35,36}$. In DNDC, $\mathrm{N}_{2} \mathrm{O}$ emissions were determined based on denitrification and nitrification pathways as a function of climate, crop growth and soil environmental factors. DNDC was parameterized for winter wheat by using published values ${ }^{37}$ and site specific data. Comparison between modelled and measured yields is shown in Fig. 4. Modelled yields compare quite well with observations, considering the average values (8.64 and $8.65 \mathrm{t} / \mathrm{ha}$ respectively) and statistics (RMSE of $1.02 \mathrm{t} / \mathrm{ha}$ and $\mathrm{MBE} \%$ of 12\%). Miscanthus parameters in the DNDC model had been parameterized using literature data and tested earlier ${ }^{18}$ calibrated and validated using observed yields over four years at a site in Urbana, Illinois, USA. To use the model under UK condition, we recalibrated the parameters using measured Miscanthus DMYs from 1997 to 2004 in the Rothamsted 408 trial $^{31}$, soil parameters for a clay loam (Batcombe series) and locally recorded weather data. The simulated and observed DMYs are displayed in Fig. 4, with RMSE of $1.57 \mathrm{t} / \mathrm{ha}$, and MBE \% of $11 \%$.

Table 1.

Figure 3. 
$1 \quad$ Figure 4.

$2 \quad$ Figure 5.

3 Table 2.

2.2 Inputs for feedstock scenario simulations

The catchment used for the scenario simulation covers an area of $5,856 \mathrm{~km}^{2}$ and comprised 48 soil series according to UK National Soil Map (1 km grid) (NATMAP vector, Cranfield University, 2001), which can be grouped in to nine soil texture classes (Fig. 5). The input data source and the target modelling outputs were listed in Table 2. Key soil information includes soil texture, SOC, bulk density, $\mathrm{pH}$, soil available water capacity (AWC) within rooting depth. STAMINA modelling framework requires information on air temperature, precipitation, wind speed, solar radiation and atmospheric humidity. In this work, three climate scenarios were examined, i.e. baseline, medium and high $\mathrm{CO}_{2}$ emissions. Hourly data collected from High Mowthorpe weather station from 1961-1990 were used for baseline simulation, assuming an atmospheric $\mathrm{CO}_{2}$ concentration of $352 \mathrm{mg}$ litre ${ }^{-1}$. Weather data were generated for the medium and high emissions scenarios using UK Climate Projections (UKCP09) ${ }^{38,39}$. In the UKCP 09, $\mathrm{CO}_{2}$ emissions under the three IPCC SRES scenarios A1FI, A1B1 and B1 are used and labelled High, Medium and Low according to how different emissions pathways affect future climate. We used the projected $\mathrm{CO}_{2}$ concentrations for 2030 of $447 \mathrm{mg}$ litre $^{-1}$ for the Medium (A1B) and 449mg litre ${ }^{-1}$ for the High (A1F1) Scenario as average $\mathrm{CO}_{2}$ concentrations for 2020-2050 timeframe ${ }^{40}$.

In the DNDC modelling, we applied an approach similar to that of $\mathrm{Guo}^{21}$ who simulated $\mathrm{N}$ and C dynamics using 5 years' of weather data (1986 to 1990) and an atmospheric $\mathrm{CO}_{2}$ concentration of $360 \mathrm{mg}$ litre $^{-1}$. In addition to the weather data, DNDC also requires $\mathrm{N}$ 
concentration in the rainfall, atmospheric $\mathrm{NH}_{3}$ concentration and fertiliser application information. Rainfall $\mathrm{N}$ concentration were derived from the UK Eutrophying and Acidifying Pollutant Network (UKEAP). The calculated 5 years mean rainfall $\mathrm{NH}_{4}{ }^{+}-\mathrm{N}$ and $\mathrm{NO}_{3}^{-}-\mathrm{N}$ concentration at Thorganby station of $1.27 \mathrm{mg}^{-1}$ litre $^{-1}$ was applied in this study. Atmospheric $\mathrm{NH}_{3}$ 5-year average concentration obtained from UKEAP-National Ammonia Monitoring Network (Easingwold station) of $2.54 \mu \mathrm{gN} / \mathrm{m}^{3}$ was applied in this study. $\mathrm{N}$ fertiliser type is assumed to be ammonium nitrate. For winter wheat, the annual input values range from $160 \mathrm{kgN} / \mathrm{ha}$ to $220 \mathrm{kgN} / \mathrm{ha}$, depending on the soil series. This was calculated using DEFRA's fertiliser manual (RB209) for each soil series, based on the information including soil texture, soil total $\mathrm{N}$ level, precipitation, previous crop types and any particular crop quality (feed or backing) requirements ${ }^{41}$. For Miscanthus, $60 \mathrm{kgN} / \mathrm{ha} / \mathrm{year}$ of ammonium nitrate was assumed in the simulation.

For crop production management, the single feedstock production scenario (SP) assumes winter wheat is grown on all the arable land across the whole catchment area (Table 3). The mixed feedstock production scenario (MP) assumes that winter wheat is still the predominating crop, while Miscanthus was cultivated only on selected low quality soils ( $8 \%$ of total area), balancing $\mathrm{N}_{2} \mathrm{O}$ emissions, $\mathrm{NO}_{3}{ }^{-}$losses, wheat grain production and $\mathrm{LCB}$ feedstock provision.

Table 3.

Straw availability was estimated based on the wheat grain production level, wheat planted area, wheat grain harvest index, harvestable straw fraction, incorporation rate and competition in demand of other uses. Due to the limited availability of data on current straw production and use, we adopted a conservative estimation of winter wheat straw provision potential for the case study area. Wheat grain harvest index (HI) is simulated by the 
STAMINA-winter wheat model, resulting in a 30-year average value of 0.53 in these study scenarios. We assume that $50 \%$ of all the leaves and stems produced over the entire wheat growing season have been lost through decay by the time of harvest. The remaining $50 \%$ of the residual biomass is harvested in the first two years, however, in the third year it is left on the ground to maintain SOC content. The total harvestable straw tonnage is calculated with Equation 1, where $\mathrm{x}$ is the modelled grain yield (in t/ha, 14.5\% moisture) and 265,600 ha was estimated based on the assumption that due to rotation, $2 / 3$ of the total 398,400 ha arable land is used for winter wheat cultivation:

$$
\text { Total straw harvested }(\text { tonnes })=\left(\frac{x}{0.53}-x\right) * 0.5 *\left(1-\frac{1}{3}\right) * 265600
$$

\subsection{Life cycle assessment (LCA)}

Field to upstream factory gate LCAs were conducted for both single SPBC and MPBC scenarios. The LCA covers the emissions per unit of delivered lignocellulosic feedstock, which includes the cultivation, preparation for transport, transport to storage and transport to processing plant in defined case study locations (Fig. 6.). Within the cultivation phase the emissions are considered from upstream production of materials and raw material extraction, fuel inputs required for on-farm cultivation, as well as direct and indirect $\mathrm{N}_{2} \mathrm{O}$ emissions. Indirect $\mathrm{N}_{2} \mathrm{O}$ emissions due to $\mathrm{NO}_{3}{ }^{-}$leaching were estimated based on modelled $\mathrm{NO}_{3}{ }^{-}$ leaching values and IPCC default emission factor EF5 ${ }^{42}$.

Table 4.

Figure 6.

LCA inputs for wheat and Miscanthus cultivation are shown in Table 4. For wheat straw, general agricultural data for operations on the field (including machinery use and associated 
diesel consumption) is taken from the BEAT database which derives its data from the Farm Management Pocketbook $^{43}$. The cultivation processes include ploughing, harrowing, fertiliser application, top dress, pesticide application, combine harvesting, and straw baling and carting. As defined by the BEAT database, the wheat straw is naturally dried in storage with no additional inputs apart from its offloading and loading from the storage location. Transport is assumed to be bulk freight road transport using $>32 t$ gross weight vehicles as defined in the Ecoinvent database ${ }^{44}$. Diesel consumption for loading and offloading of feedstocks is calculated basing on the movement of 15 t/hour feedstock with the consumption of $493 \mathrm{MJ} /$ hour diesel ${ }^{45}$. To maintain consistency with the DNDC simulations, same amounts of ammonium nitrate input levels were adopted in LCA and DNDC simulations. The remaining cultivation data for Miscanthus (including subsoiling, ploughing, harrowing, fertiliser application, spraying, weed cultivation and residue removal) has been compiled from the Sustainable Liquid Biofuels from Biomass Biorefining (SUNLIBB) project database $^{46}$, which has been developed for Europe primarily from UK data. Transport is assumed to be same as above for wheat straw. Upstream data for the production of the inputs specified in the feedstock cultivation input trees is taken from Ecoinvent v3.1 ${ }^{44}$. The combustion of diesel in agricultural equipment for various tasks (e.g. fertiliser application, harvesting, baling etc.) is taken from IPCC ${ }^{22}$ and Kubica et al. $^{47}$. The environmental impacts associated with this data is calculated in Simapro 8 using the ReCiPe Midpoint (H) LCA impact assessment methodology.

As cultivation data count for the whole wheat crop, the impacts of cultivation need to be allocated to wheat grain or straw. Three allocation methods were applied in this work, i.e. economic allocation, RED_allocation and CV_allocation. Economic data for wheat straw and grain taken from Statistics Denmark show prices of $€ 0.074$ and $€ 0.15 / \mathrm{kg}$, respectively, assuming provision of the public good 'straw for energy'48. According to Renewable Energy 
Accepted manuscript of article accepted for publication in Biofuels, Bioproducts and Biorefining

1 Directive (EU RED) ${ }^{49}$, straw shall be considered to have zero life-cycle GHG emissions up

2 to the process of collection of those materials. Additionally, we allocated emissions based

3 on the real calorific values $(\mathrm{CV})$ of wheat grain and straw, which are 16.5 and $17.6 \mathrm{MJ} / \mathrm{kg}$,

4 respectively ${ }^{50}$.

\section{$5 \quad 3 \quad$ RESULTS}

3.1 Single feedstock production scenarios

Modelled 30-year average grain yields for all the soil series range from 7.20 to $8.33 \mathrm{t} / \mathrm{ha}$ (14. 5\% moisture), depending on variable soil AWC. Weighted average yield was calculated basing on the proportion of each soil series in total area. The overall weighted average yield in the region is $7.94 \mathrm{t} / \mathrm{ha}(14.5 \%$ moisture). Yields were also simulated for medium and high emission climate change scenarios (Table 4). Like in the baseline results, soils of high AWC can achieve slightly higher yields. The overall weighted average yields are 8.54 and 8.76 t/ha for medium and high emission scenarios respectively. Total amount of harvestable wheat straw are estimated to be 623,670 and $688 \mathrm{kt} /$ year for the chosen catchment area under baseline, medium and high emission scenarios, respectively (Table 5). About 97\% of the current wheat straw currently has other uses ${ }^{4,6,8}$ (Fig. 1), which is 604kt per year. Under the medium and high emission scenario, assuming the annual demands from other uses will remain stable, then a total amount of 66 and $83 \mathrm{kt}$ wheat straw could become available for bioenergy or biomaterial production.

Table 5 .

Figure 7.

Simulated $\mathrm{NO}_{3}{ }^{-}$leaching and winter wheat grain yields of different soil textures show a high variation in $\mathrm{NO}_{3}{ }^{-}$leaching and gas flux from different soil textures (Fig. 7) in the DNDC outputs. $\mathrm{NO}_{3}{ }^{-}$leaching is the main sink for $\mathrm{N}$ loss; depending on soil texture, the 4-year 
average $\mathrm{NO}_{3}{ }^{-}$leached ranges between 14 and $135 \mathrm{kgN} / \mathrm{ha} /$ year. The annual leaching fractions $\left(\mathrm{NO}_{3}{ }^{-}\right.$leached per $\mathrm{N}$ fertiliser inputs) for different soil textures range from 6 to $60 \%$ of total applied $\mathrm{N}$. The weighted average leaching amount is $63.3 \mathrm{~kg} \mathrm{~N} / \mathrm{ha}$ which corresponds to a leaching fraction of $30 \%$.

These results are similar to the IPCC Tier 1 estimate for FracLEACH-(H) (N losses by leaching/runoff for regions), according to which the rate of $\mathrm{N}$ loss by leaching or run off is $30 \%$ of the total $\mathrm{N}$ fertiliser input, with an uncertainty range of 10 to $80 \%^{22}$. This result is also in accordance with the winter wheat long-term field trial 'Broadbalk Experiment' conducted in England, where 21\% and 31\% N loss were observed for the 192 and 240kgN/ha $\mathrm{N}$ fertiliser application treatments, respectively ${ }^{51}$.

\subsection{Mixed feedstock production scenarios}

In the mixed feedstock production (MP) scenarios, Miscanthus was assumed to be planted on all those soils with loamy fine sand texture. For those soils, simulated winter wheat yields are much lower than on the other soils while the $\mathrm{N}$ leaching is substantially higher than finer textured soils (Fig. 7). On these soils, the Miscanthus produces about 1213t/ha, compared to only 1.5 to 2.0 t/ha of winter wheat straw becoming available. The comparison of modelled $\mathrm{NO}_{3}^{-}$leaching and $\mathrm{N}_{2} \mathrm{O}$ emissions between wheat straw and Miscanthus on those four loamy fine sand soils are shown in Fig. 8. Similar to winter wheat production, model outputs also show a positive effect of increasing $\mathrm{CO}_{2}$ concentration on Miscanthus production (Table 6). Compared with the SP scenario, total available LCB increases from $19 \mathrm{kt}$ (SPBC) to $384 \mathrm{kt}$ (MPBC) under the baseline climate. Under the medium and higher climate change scenarios, the differences increase from 365 to $504 \mathrm{kt}$ and $545 \mathrm{kt}$ total available LCB production, respectively (Fig. 9).

Figure 8 . 
Figure 9.

About $11 \%$ of $\mathrm{NO}_{3}{ }^{-}$leaching could be prevented when MPBC feedstock scenarios were adopted (Table 7), equating to a saving of approximately 2.81 million $\mathrm{kg}$ N/year. A relatively minor reduction $(6.06 \%)$ in direct $\mathrm{N}_{2} \mathrm{O}$ emissions is estimated by DNDC (0.66kgN/ha for SPBC and $0.62 \mathrm{kgN} / \mathrm{ha}$ for MPBC). In total, $34,925 \mathrm{~kg} \mathrm{~N} /$ year $(10,408 \mathrm{t}$ $\mathrm{CO}_{2}$ eq/year) $\mathrm{N}_{2} \mathrm{O}$ emission could be saved moving from SPBC to MPBC feedstocks.

\section{Table 7.}

\subsection{LCA results}

The direct and indirect $\mathrm{N}_{2} \mathrm{O}$ emission results were included in the field to upstream factory gate LCA for both SPBC and MPBC scenarios (Fig. 10). When economic allocation was applied, the LCA shows an impact of $0.20 \mathrm{~kg} \mathrm{CO} 2 \mathrm{eq} / \mathrm{kg}$ delivered LCB for SPBC scenario, and this figure decreases for 52\% in MPBC system. A similar trend can be found when CV allocation was used. However if RED allocation was considered, the GWP for SPBC is only $0.020 \mathrm{~kg} \mathrm{CO}_{2} \mathrm{eq} / \mathrm{kg}$ and increases to $0.087 \mathrm{~kg} \mathrm{CO} 2 \mathrm{eq} / \mathrm{kg}$ when MPBC was adopted. This is due to that RED allocation approach requires all the emissions of wheat cultivation to be attributed to grain production. It can also be noted that cultivation phrase contributes to the biggest portion of GWP (from $77 \%$ to $94 \%$ ) in all the scenarios except SP when RED allocation is used. Furthermore, $\mathrm{N}_{2} \mathrm{O}$ emission accounts for $14 \%$ to $16 \%$ of total emissions except for SPBC scenario under RED allocation.

Figure 10. 
In this study, the process based models DNDC and STAMINA, were calibrated and evaluated for winter wheat and Miscanthus under local English conditions. Both models simulated yields quite well when compared to observed yields for both crops. DNDC has been widely used for simulating $\mathrm{C}$ and $\mathrm{N}$ dynamics for a range of crops. However, as Miscanthus was not included in the original version of the model, only two articles have been published using DNDC to simulate Miscanthus growth before ${ }^{18,52}$. In the work reported here, we tested the DNDC model's performance in simulating Miscanthus yields under local conditions, however, uncertainty remains on the model's ability to accurately simulate $\mathrm{N}$ dynamics, for which it was not possible to calibrate the model in this work.

Due to the lack of information on current straw production and use, a conservative estimate of winter wheat straw provision potential was adopted. It has been suggested that straw which was used for animal bedding could be used locally for soil incorporation after (serving as farmyard manure), allowing substantial reduction of the incorporated straw and making more straw available for bio-energy or bio-material production. However, this is less likely to happen considering current records from Copeland and Turley ${ }^{6}$ according to which a large volume of straw is moved from the Eastern Counties to the South West of England, Wales and Scotland to meet the market demands for animal bedding in the livestock sector ${ }^{7}$, rather than being used locally.

Medium and high $\mathrm{CO}_{2}$ emission climate change scenarios were used to model production of winter wheat and Miscanthus, however, as both STAMINA and UKCP only examine the impacts of altered atmospheric factors $\left(\mathrm{CO}_{2}\right.$ concentration, rainfall, temperature etc.) on crop growth, they do not include issues such as altered occurrence of pest and diseases, which are likely to impact on yields. Based on simulations of projected $\mathrm{CO}_{2}$ concentration and corresponding weather information from the UKCP, no negative impacts on wheat and 
1 Miscanthus yields have been seen. On the contrary, our simulations predict increases of $7.6 \%$ and $10.3 \%$ for wheat grain yields under medium and high scenarios respectively, and $33.9 \%$ and $43.2 \%$ increase of Miscanthus yields compared with the baseline climate. Simulated increases in wheat productivity were in accordance with most of the current research in that $\mathrm{C} 3$ crops show yield increases in response to rising $\mathrm{CO}_{2}$ concentration through increased rates of photosynthesis and decreased water use ${ }^{53}$. Unlike C3 crops, the impacts of elevated $\mathrm{CO}_{2}$ concentration on $\mathrm{C} 4$ crops growth remains uncertain ${ }^{53}$. In theory, the increase of biomass from elevated atmospheric $\mathrm{CO}_{2}$ concentration on $\mathrm{C} 4$ crops should be very limited or even none, however this has been shown only in some of the research conducted $^{53}$, whilst others have seen substantial increases in photosynthesis and biomass production at increased $\mathrm{CO}_{2}$ concentrations ${ }^{54,55}$. Apart from the elevated $\mathrm{CO}_{2}$ concentration, our simulated increases in Miscanthus yields under climate change scenarios could be explained by the much warmer climate $(48.71 \%$ and $46.67 \%$ higher average hourly temperatures), higher average humidity (13.91\% and $14.21 \%$ higher humidity) and slightly higher annual precipitation levels $(2.51 \%$ and $2.56 \%$ higher annual rainfall) projected by UKCP compared with the baseline climate. It has been widely discussed that Miscanthus growth in Northern Europe is mainly constrained from reaching its potential by the cold temperature ${ }^{11,56}$.

Comparing our estimated total available LCB for single and mixed feedstock production under different climate change scenarios, it is clear that the proposed MP scenarios benefit significantly more than the SP scenarios. Under the SP scenarios, it is impossible to ensure sufficient feedstock for a new development of an exclusively locally supplied lignocellulosic biofuel or biomaterial plant in the case study area, even for the SPHE scenario, when the available LCB is estimated to be $82 \mathrm{kt} /$ year. However, if the $8 \%$ selected area with low quality soils were to be converted to Miscanthus cultivation, available LCB supply is 
estimated to be $383 \mathrm{kt} / \mathrm{year}$ for MPBC and 628kt/year for MPHE, which is sufficient to support one to two commercial scale lignocellulosic biofuel or biomaterial plants, with $3 \%$ reduction in regional wheat grain supply.

The simulated and estimated $\mathrm{NO}_{3}{ }^{-}$leaching and $\mathrm{N}_{2} \mathrm{O}$ emissions of both $\mathrm{SPBC}$ and MPBC scenarios indicated that if Miscanthus is integrated into the arable system by replacing conventional cereal crops on low-quality soils (where wheat production levels are lower and $\mathrm{N}$ losses higher), weighted average $\mathrm{NO}_{3}{ }^{-}$leaching across the whole feedstock supply region would be reduced by $10 \%$ and the total of direct and indirect $\mathrm{N}_{2} \mathrm{O}$ emissions would be reduced by $8 \%$. The reduction of GWP from SPBC to MPBC scenario becomes larger according to the LCA results, due to the reduced fertiliser application, machinery use and associated energy consumption.

When calculating GWP from agricultural residues, the choice of allocation method is crucial in deciding the LCA results. In this work, when RED allocation is used, the results were completely in contrary to those using economic allocation and $\mathrm{CV}$ allocation. It suggests that the current allocation method in RED is too simplified to reflect the real GHG dynamics reliably, especially when comparison with perennial crops is made.

Assessing the $\mathrm{C}$ stock impacts arising from the change in land use from wheat to Miscanthus was outside the scope of this work. However, a few studies have shown C stock increases for arable land converted to Miscanthus, in both above ground biomass and below ground $\mathrm{C}_{\text {pool }}{ }^{57-60}$. Our recent analyses show that soil carbon enrichment under Miscanthus can be marginal on soils rich in carbon ${ }^{9}$ but considerable in low quality soils ${ }^{61}$. Thus, we would expect to see a further reduction of GWP by moving from SPBC to MPBC as C stocks would increase from land use change to perennial crops. GWP arising from land use change will be assessed in an additional paper. 
GWP of the non-food bioeconomy can be improved considerably (5-6\%) when LCB resourcing is changed from a SPBC to a MPBC system. Integrating Miscanthus on sandy soils into the UK arable system improves the feedstock availability omitting low yield and high $\mathrm{N}$ loss locations for wheat production. In such an MP scenario, total available LCB increases by more than an order of magnitude with limited impact on wheat production. Simulated $\mathrm{NO}_{3}{ }^{-}$leaching and $\mathrm{N}_{2} \mathrm{O}$ emissions from Miscanthus production are $50 \%$ to $60 \%$ lower than from wheat on these low-quality soils, showing a win-win situation regarding environmental and economic criteria. bioeconomy: 
1 limited to the case study area, so the methodology we proposed should also be tested with 2 broader applications.

We thank the European Commission's Climate-KIC programme for financial support provided in the context of the project Adaptation and Mitigation through Bio-Succinate Innovation (ADMIT Bio-SuccInnovate). Co-authors Qi and Richter acknowledge the support by the UK Engineering Physical Sciences Research Council (EPSRC), through grant EP/K036734/1 "Bioenergy value chains: Whole systems analysis and optimisation" (Supergen Bioenergy Challenge) and by Rothamsted Research's Institute Strategic Programmes "Soil to Nutrition" (BB/PO1268X/1) and "ASSIST" (BBS/E/C/000I0110) funded by the UK Biotechnology and Biological Sciences Research Council (BBSRC).

7 REFERENCES

1. Black MJ, Whittaker C, Hosseini SA, Diaz-Chavez R, Woods J, Murphy RJ, Life Cycle Assessment and sustainability methodologies for assessing industrial crops, processes and end products. Ind Crops Prod 34:1332-1339 (2011).

2. Hammerschlag R. Ethanol's energy return on investment: A survey of the literature 1990 Present. Environ Sci Technol 40:1744-1750 (2006).

3. Donaldson E, Schillinger WF, Dofing SM, Straw production and grain yield relationships in winter wheat. Crop Sci 41:100-106 (2001).

4. Glithero NJ, Wilson P, Ramsden SJ. Straw use and availability for second generation biofuels in England. Biomass and Bioenergy 55:311-321 (2013).

5. Engel R, Long D, Carlson G, Wallander R. Estimating straw production of spring and winter 
Accepted manuscript of article accepted for publication in Biofuels, Bioproducts and Biorefining

wheat. Fertilizer Facts Montana State University Extention Bulletin 33 (2005)

6. Copeland J, Turley D. National and regional supply/demand balance for agricultural straw in Great Britain. (2012). [Online]. Available at: http://www.northwoods.org.uk/northwoods/files/2012/12/StrawAvailabilityinGreatBritain .pdf [April 26, 2017]

7. Rosillo-Calle F, De Groot P, Hemstock SL, Woods J, editors. The biomass assessment handbook: Energy for a sustainable environment. Routledge (2015).

8. Nicholson, F., Kindred, D., Bhogal, A., Roques, S., Kerley, J., Twining, S., Brassington, T., Gladders, P., Balshaw, H., Cook, S., Research Review No. 81. Straw incorporation review. (2014). [Online]. Available at: https://cereals.ahdb.org.uk/media/470361/rr81-web.pdf [April 26, 2017]

9. Richter GM, Agostini F, Redmile-Gordon M, White R, Goulding KWT, Sequestration of C in soils under Miscanthus can be marginal and is affected by genotype-specific root distribution. Agric Ecosyst Environ 200:169-177 (2015).

10. CLIFTON-BROWN JC, Breuer J, Jones MB, Carbon mitigation by the energy crop, Miscanthus. Glob Chang Biol. 13:2296-307 (2007).

11. Lewandowski I, Clifton-Brown JC, Scurlock JM, Huisman W, Miscanthus: European experience with a novel energy crop. Biomass and Bioenergy. 19:209-227 (2000).

12. Patel M, Crank M, Dornberg V Hermann B, Roes L, Hüsing B et al., Medium and Longterm Opportunities and Risks of the Biotechnological Production of Bulk Chemicals from Renewable Resources - The Potential of White Biotechnology. Utrecht University, Department of Science, Technology and Society (STS)/Copernicus Institute, Utrecht (2006). [Online]. Available at: http://edepot.wur.nl/183326 [April 13, 2018].

13. Philp J, Biobased chemicals and bioplastics: Finding the right policy balance. Ind Biotechnol. 10:379-383 (2014). 
Accepted manuscript of article accepted for publication in Biofuels, Bioproducts and Biorefining

1 14. Diaz-chavez R. Socio-Economic Impacts of Bioenergy Production. (2014). [Online].

2 Available from: http://link.springer.com/10.1007/978-3-319-03829-2 [April 13, 2018]

15. Christian DG, Quantifying the yield of perennial grasses grown as a biofuel for energy generation. Renew Energy 5:762-766 (1994).

16. Christian DG, Riche AB, Nitrate leaching losses under Miscanthus grass planted on a silty clay loam soil. Soil Use Manag 14:131-135 (1998).

17. Christian DG, Riche AB, Yates NE, Growth, yield and mineral content of Miscanthus $x$ giganteus grown as a biofuel for 14 successive harvests. Ind Crops Prod 28:320-27 (2008).

18. Gopalakrishnan G, Cristina Negri M, Salas W, Modeling biogeochemical impacts of bioenergy buffers with perennial grasses for a row-crop field in Illinois. GCB Bioenergy 4:739-750 (2012).

19. Heaton EA, Dohleman FG, Long SP, Meeting US biofuel goals with less land: The potential of Miscanthus. Glob Chang Biol 14:2000-2014 (2008).

20. Hellebrand HJ, Scholz V, Kern J, Fertiliser induced nitrous oxide emissions during energy crop cultivation on loamy sand soils. Atmos Environ 42:8403-8411 (2008).

21. Guo M, Li C, Bell JNB, Murphy RJ, Influence of agro-ecosystem modeling approach on the greenhouse gas profiles of wheat-derived biopolymer products. Environ Sci Technol 46:320-330 (2012).

22. Garg A, Kazunari K, Pulles T, 2006 IPCC guidelines for national greenhouse gas inventories. Intergovernmental Panel on Climate Change (2006). [Online]. Available from: https://www.ipcc-nggip.iges.or.jp/public/2006gl/ [April 13, 2018].

23. Goglio P, Smith WN, Grant BB, Desjardins RL, Gao X, Hanis K, Tenuta M, Campbell CA, McConkey BG, Nemecek T, Burgess PJ, A comparison of methods to quantify greenhouse gas emissions of cropping systems in LCA. J Clean Prod 172:4010-4017 
Accepted manuscript of article accepted for publication in Biofuels, Bioproducts and Biorefining

1

2

3

4

(2018).

24. Fisher S, Karunanithi A, Contemporary comparative LCA of commercial farming and urban agriculture for selected fresh vegetables consumed in Denver, Colorado. Proc 9th Int Conf Life Cycle Assess Agri-Food Sect. (2014). [Online] Available from: $\underline{\text { http://citeseerx.ist.psu.edu/viewdoc/download?doi=10.1.1.832.8968\&rep=rep1\&type=pdf }}$ [April 13, 2018].

25. Richter GM, Rana G, Ferrara RM, Ventrella D, Acutis M, Trevisiol P, Mayr Th, Baggeley N, Morris, J, Holmes A, Trawick P, Dailey AG, Robbins P, Simota C, Stability and mitigation of arable systems in hilly landscapes. EU-QLK-5-CT-2002-013013. Report to the European Commission, Brussels. (2006).

26. Li C, Farahbakhshazad N, Jaynes DB, Dinnes DL, Salas W, McLaughlin D, Modeling nitrate leaching with a biogeochemical model modified based on observations in a rowcrop field in Iowa. Ecol Modell 196:116-130 (2006).

27. Ferrara RM, Trevisiol P, Acutis M, Rana G, Richter GM, Baggaley N, Topographic impacts on wheat yields under climate change: two contrasted case studies in Europe. Theor Appl Climatol 99:53-65 (2010).

28. Richter GM, Semenov MA, Modelling impacts of climate change on wheat yields in England and Wales: Assessing drought risks. Agric Syst.;84:77-97 (2005).

29. Schapendonk AHC., Stol W, van Kraalingen DW., Bouman BA, LINGRA, a sink/source model to simulate grassland productivity in Europe. Eur J Agron 9:87-100 (1998).

30. Richter GM, Qi A, Semenov M a., Jaggard KW, Modelling the variability of UK sugar beet yields under climate change and husbandry adaptations. Soil Use Manag 22:39-47 (2006) 
Accepted manuscript of article accepted for publication in Biofuels, Bioproducts and Biorefining

1 31. Richter GM, Riche AB, Dailey AG, Gezan SA, Powlson DS, Is UK biofuel supply from

$2 \quad$ Miscanthus water-limited? Soil Use Manag 24:235-245 (2008).

32. Giltrap DL, Singh J, Saggar S, Zaman M, A preliminary study to model the effects of a nitrification inhibitor on nitrous oxide emissions from urine-amended pasture. Agric Ecosyst Environ 136:310-317 (2010).

33. Abdalla M, Jones M, Yeluripati J, Smith P, Burke J, Williams M, Testing DayCent and DNDC model simulations of $\mathrm{N}_{2} \mathrm{O}$ fluxes and assessing the impacts of climate change on the gas flux and biomass production from a humid pasture. Atmos Environ 44:2961-2970 (2010).

34. Kesik M, Brüggemann N, Forkel R, Kiese R, Knoche R, Li C, et al., Future scenarios of N $2 \mathrm{O}$ and NO emissions from European forest soils. J Geophys Res 111 (2006).

35. Giltrap DL, Li C, Saggar S, DNDC: A process-based model of greenhouse gas fluxes from agricultural soils. Agric Ecosyst Environ 136:292-300 (2010).

36. Li C, Modeling trace gas emissions from agricultural ecosystems. Nutr Cycl Agroecosystems 259-276 (2000).

37. Wattenbach M, Sus O, Vuichard N, Lehuger S, Gottschalk P, Li L, et al., The carbon balance of European croplands: A cross-site comparison of simulation models. Agric Ecosyst Environ 139:419-453(2010).

38. Jenkins G, Murphy J, Sexton D, Lowe J, Jones P, Kilsby C, UKCP09 Briefing report (2009). [Online]. Available from: http://ukclimateprojections.defra.gov.uk/media.jsp?mediaid=87852\&filetype=pdf [April $13,2018]$

39. Murphy JM, Sexton DM, Jenkins GJ, Booth BB, Brown CC, Clark RT, Collins M, Harris GR, Kendon EJ, Betts RA, Brown SJ, UK climate projections science report: climate 
Accepted manuscript of article accepted for publication in Biofuels, Bioproducts and Biorefining

change projections. (2009). [Online]. Available from: http://ukclimateprojections.metoffice.gov.uk/media.jsp?mediaid=87893 [April 13, 2018].

40. IPCC Data Distribution Centre. ( 2014). [Online]. Available from: http://www.ipccdata.org/ancilliary/tar-bern.txt [April 13, 2018].

41. Department of the Environmetnal, Food and Rural Affairs, Fertiliser Manual (RB209). (2010) [Online]. Available from: https://ahdb.org.uk/documents/rb209-fertiliser-manual110412.pdf [April 13, 2018].

42. IPCC. Indirect $\mathrm{N}_{2} \mathrm{O}$ Emissions from Agriculture. Good Practice Guidance and Uncertainty Management in National Greenhouse Gas Inventories.(2000). [Online]. Available from: https://www.ipccnggip.iges.or.jp/public/gp/bgp/4_6_Indirect_N2O_Agriculture.pdf [April 13, 2018].

43. Nix JS, Farm management pocketbook 2008. The Anderson Centre (2007).

44. Wernet G, Bauer C, Steubing B, Reinhard J, Moreno-Ruiz E, Weidema B. The ecoinvent database version 3 (part I): overview and methodology. Int J Life Cycle Assess 21:12181230 (2016).

45. Grant JF, Hetherington R, Horne RE, Mortimer ND. Energy and carbon analysis of using straw as a fuel. (1995). [Online]. Available from: https://inis.iaea.org/search/search.aspx?orig_q=RN:26063228. [April 13, 2018].

46. Mortimer ND, Hatto C, Mwabonje O. Sustainable Liquid Biofuels from Biomass Biorefining(SUNLIBB). (2014).

47. Kubica K, Paradiz B, Dilara P, Klimont Z, Kakareka S, Debsk B, EMEP/EEA air pollutant emission inventory guidebook. (2009). [Online]. Available from: https://www.eea.europa.eu/publications/emep-eea-emission-inventory-guidebook-2009 [April 13, 2018].

48. Statistics Denmark. Kapit1:Farm gate prices on barley and wheat by defined districts and 
Accepted manuscript of article accepted for publication in Biofuels, Bioproducts and Biorefining

type of crop.(2015). [Online]. Available from: http://www.statbank.dk/KAPIT1 [April 13, 2018]

49. European Parliament and Council. Directive 2009/28/EC of 23 April 2009 on the promotion of the use of energy from renewable sources.(2009) [Online]. Available from: http://eurlex.europa.eu/LexUriServ/LexUriServ.do?uri=OJ:L:2009:140:0016:0062:EN:PD F [July 13, 2018]

50. BSI. BS EN 14961-1: 2010 Solid Biofuels. Fuels Specifications and Classes. General Requirements. (2010). London: British Standards Institution.

51. Brentrup F, Palliere C, Nitrogen use efficiency as an agro-environmental indicator. (2010). [Online]. Available from: http://www.oecd.org/tad/sustainableagriculture/44810448.pdf [April 16, 2017]

52. Borzcka-Walker M, Faber A, Kozyra J, Pudelko R, Mizak K, Syp A, Modelling Impact of Climate Change on Willow and Miscanthus Potential Productivity in Poland. J Food, Agric Environ 10:1437-1440 (2010).

53. de Souza AP, Arundale RA, Dohleman FG, Long SP, Buckeridge MS, Will the exceptional productivity of Miscanthus x giganteus increase further under rising atmospheric $\mathrm{CO}_{2}$ ? Agric For Meteorol 171:82-92 (2013).

54. de Souza AP, Gaspar M, Da Silva EA, Ulian EC, Waclawovsky AJ, Nishiyama MY, et al., Elevated $\mathrm{CO}_{2}$ increases photosynthesis, biomass and productivity, and modifies gene expression in sugarcane. Plant, Cell Environ. 31:1116-1127 (2008).

55. Ottman MJ, Kimball BA, Pinter PJ, Wall GW, Vanderlip RL, Leavitt SW, et al., Elevated $\mathrm{CO}_{2}$ increases sorghum biomass under drought conditions. New Phytol 150:261-273 (2001).

56. Kandel TP, Hastings A, Jørgensen U, Olesen JE, Simulation of biomass yield of regular and chilling tolerant Miscanthus cultivars and reed canary grass in different climates of 
Accepted manuscript of article accepted for publication in Biofuels, Bioproducts and Biorefining

Europe. Ind Crops Prod 86:329-333 (2016).

57. Harris ZM, Spake R, Taylor G, Land use change to bioenergy: A meta-analysis of soil carbon and GHG emissions. Biomass and Bioenergy 82:27-39 (2015).

58. Hansen EM, Christensen BT, Jensen LS, Kristensen K. Carbon sequestration in soil beneath long-term Miscanthus plantations as determined by $13 \mathrm{C}$ abundance. Biomass and Bioenergy 26:97-105 (2004).

59. Hillier J, Whittaker C, Dailey G, Aylott M, Casella E, Richter GM, et al., Greenhouse gas emissions from four bioenergy crops in England and Wales: Integrating spatial estimates of yield and soil carbon balance in life cycle analyses. GCB Bioenergy 1:267-281 (2009).

60. Dondini M, Alberti G, Delle Vedove G, Ventura M, Tonon G, Viger M, Harris ZM, Jenkins JR, Richards M, Pogson M, Taylor G, Evaluation of the ECOSSE model to predict heterotrophic soil respiration by direct measurements. Eur J Soil Sci 68:384-493 (2017).

61. Gregory AS, Dungait JAJ, Shield IF, Macalpine WJ, Cunniff J, Durenkamp M, et al., Species and Genotype Effects of Bioenergy Crops on Root Production, Carbon and Nitrogen in Temperate Agricultural Soil. BioEnergy Research 11 (2):382-97 (2018). 
Accepted manuscript of article accepted for publication in Biofuels, Bioproducts and Biorefining

1 Table Caption

2 Table 1. Three data sets used for model calibration for winter wheat and Miscanthus

3 Table 2. Specifications of models inputs and outputs

$4 \quad$ Table 3. Single and mixed crop production (SP, MP) and climate change scenarios Baseline

5 Climate (BC), Medium Emission (ME) and High Emission (HE); atmospheric carbon dioxide

6 concentration $\left[\mathrm{CO}_{2}\right]$

$7 \quad$ Table 4. Life cycle inventory for wheat and Miscanthus cultivation used in this study

8 Table 5. Weighted average grain yield outputs and total annual collectable straw in

$9 \quad$ catchment area based on STAMINA-winter wheat

Table 6. Simulated Miscanthus yield (and standard deviation) on selected loamy fine sand

11 soils

12

Table 7. $\mathrm{NO}_{3}{ }^{-}$Leaching and $\mathrm{N}_{2} \mathrm{O}$ emissions (and standard deviation) of SPBC and MPBC scenarios 
Accepted manuscript of article accepted for publication in Biofuels, Bioproducts and Biorefining

$1 \quad$ Figure Legends

2 Figure 1. Estimated current straw use in UK based on literature, total straw production estimate ranges from $10.70^{8}$ to $11.88 \mathrm{Mt} /$ year $^{6}$

Figure 2. Map showing the case study area-50km radius of Hull

Figure 3. STAMINA model evaluation results for winter wheat and miscanthus

Figure 4. DNDC model evaluation results for winter wheat and miscanthus

Figure 5. Proportion of each soil type in total case study catchment

Figure 6. Process flow diagram showing the LCA system boundary used in this study

Figure 7. Simulated $\mathrm{NO}_{3}{ }^{-}$leaching rate and average annual grain yield for winter wheat production for different soil texture groups

Figure 8. (a) $\mathrm{NO}_{3}{ }^{-}$leaching and (b) direct $\mathrm{N}_{2} \mathrm{O}$ emission from winter wheat straw and Miscanthus cultivation on selected soils under baseline climate scenario

Figure 9. Total LCB provision for SP and MP scenarios

Figure 10. GWP of LCB delivered to feedstock processing plant under SPBC and MPBC scenarios

(16)


Accepted manuscript of article accepted for publication in Biofuels, Bioproducts and Biorefining

$1 \quad$ Table 1. Three data sets used for model calibration for winter wheat and Miscanthus

$\begin{array}{lll}\text { Crop } & \text { Site } & \text { Years of Simulation }\end{array}$

Winter wheat

Rosemaund (R) 1993-1996

Gleadthorpe (G) 1991-1994

Boxworth (B) 1993-1995

2

3

4

5

6

7

8

9

10

11

12

13 
Table 2. Specifications of models inputs and outputs

\begin{tabular}{|c|c|c|c|c|c|}
\hline & Soil & Weather & Background N & $\begin{array}{l}\mathbf{N} \text { fertiliser } \\
\text { inputs }\end{array}$ & Output \\
\hline STAMINA & NATMAP* & $\begin{array}{l}\text { Hourly data from } \\
\text { High Mowthorpe } \\
\text { weather station } \\
\text { (1961-1990) }\end{array}$ & $\begin{array}{l}\text { Not needed; } \\
\text { assumed to be } \\
\text { non-limiting }\end{array}$ & Not needed & $\begin{array}{l}\text { Yield for } 30 \text { years } \\
\text { winter wheat } \\
\text { and Miscanthus } \\
\text { cultivations }\end{array}$ \\
\hline DNDC & NATMAP* & $\begin{array}{l}\text { Daily data from } \\
\text { High Mowthorpe } \\
\text { weather station } \\
(1986-1990)\end{array}$ & $\begin{array}{l}\text { UK } \\
\text { Eutrophying } \\
\text { and Acidifying } \\
\text { Pollutant } \\
\text { Network } \\
\text { (UKEAP) }\end{array}$ & $\begin{array}{l}\text { Specific value } \\
\text { for each soil } \\
\text { series based on } \\
\text { RB209 } 41\end{array}$ & $\begin{array}{l}\mathrm{NO}_{3}{ }^{-} \text {leaching } \\
\text { and } \mathrm{N}_{2} \mathrm{O} \\
\text { emission from } \\
\text { winter wheat } \\
\text { and Miscanthus } \\
\text { cultivation from } \\
\text { 1986-1990 }\end{array}$ \\
\hline
\end{tabular}


Accepted manuscript of article accepted for publication in Biofuels, Bioproducts and Biorefining

1 Table 3. Single and mixed crop production (SP, MP) and climate change scenarios Baseline

2 Climate (BC), Medium Emission (ME) and High Emission (HE); atmospheric carbon dioxide

3 concentration $\left[\mathrm{CO}_{2}\right]$

\begin{tabular}{|c|c|c|c|c|}
\hline Scenario & Description & $\begin{array}{l}\text { Wheat cultivation } \\
\text { allocation }\end{array}$ & $\begin{array}{l}\text { Miscanthus cultivation } \\
\text { allocation }\end{array}$ & Climate change scenario \\
\hline SPBC & $\begin{array}{l}\text { Single crop Production } \\
\text { under Baseline Climate }\end{array}$ & On all arable soils & None & $\begin{array}{l}\text { Baseline weather } \\
{\left[\mathrm{CO}_{2}\right] 352 \mathrm{mg} \mathrm{l}^{-1}}\end{array}$ \\
\hline SPME & $\begin{array}{l}\text { Single crop Production } \\
\text { under Medium Emission } \\
\text { climate change }\end{array}$ & On all arable soils & None & $\begin{array}{l}\text { Medium Emission } \\
{\left[\mathrm{CO}_{2}\right] 447 \mathrm{mg} \mathrm{I}^{-1}}\end{array}$ \\
\hline SPHE & $\begin{array}{l}\text { Single crop Production } \\
\text { under High Emission } \\
\text { climate change }\end{array}$ & On all arable soils & None & $\begin{array}{l}\text { High Emission } \\
{\left[\mathrm{CO}_{2}\right] 449 \mathrm{mg} \mathrm{I}^{-1}}\end{array}$ \\
\hline MPBC & $\begin{array}{l}\text { Mixed crop Production } \\
\text { under Baseline Climate }\end{array}$ & $\begin{array}{l}\text { Excluding selected } \\
\text { low quality soils }\end{array}$ & $\begin{array}{l}\text { On Selected low } \\
\text { quality soils }\end{array}$ & $\begin{array}{l}\text { Baseline weather } \\
{\left[\mathrm{CO}_{2}\right] 352 \mathrm{mg} \mathrm{l}^{-1}}\end{array}$ \\
\hline MPME & $\begin{array}{l}\text { Mixed crop Production } \\
\text { under Medium Emission } \\
\text { climate change }\end{array}$ & $\begin{array}{l}\text { Excluding selected } \\
\text { low quality soils }\end{array}$ & $\begin{array}{l}\text { On Selected low } \\
\text { quality soils }\end{array}$ & $\begin{array}{l}\text { Medium Emission } \\
{\left[\mathrm{CO}_{2}\right] 447 \mathrm{mg} \mathrm{I}^{-1}}\end{array}$ \\
\hline MPHE & $\begin{array}{l}\text { Mixed crop Production } \\
\text { under High Emission } \\
\text { climate change }\end{array}$ & $\begin{array}{l}\text { Excluding selected } \\
\text { low quality soils }\end{array}$ & $\begin{array}{l}\text { On Selected low } \\
\text { quality soils }\end{array}$ & $\begin{array}{l}\text { High Emission } \\
{\left[\mathrm{CO}_{2}\right] 449 \mathrm{mg} \mathrm{l}^{-1}}\end{array}$ \\
\hline
\end{tabular}

4 
Table 4. Life cycle inventory for wheat and Miscanthus cultivation used in this study. project for Miscanthus.

\begin{tabular}{|c|c|c|c|}
\hline & Unit & Wheat & Miscanthus \\
\hline Seeds & $\mathrm{kg} / \mathrm{ha} /$ year & 175 & 0 \\
\hline Rhizomes & $\mathrm{kg} / \mathrm{ha} /$ year & 0 & 5921 \\
\hline Ammonium nitrate $^{a}$ & kg N/ha/year & 205 & 60 \\
\hline Triple superphosphate & $\mathrm{kg} \mathrm{P}_{2} \mathrm{O}_{5} /$ ha/year & 39 & 7 \\
\hline Potassium chloride & $\mathrm{kg} \mathrm{K}_{2} \mathrm{O} / \mathrm{ha} /$ year & 48 & 0 \\
\hline Potassium sulphate & $\mathrm{kg} \mathrm{K}_{2} \mathrm{O} / \mathrm{ha} /$ year & 0 & 105 \\
\hline Calcium oxide & $\mathrm{kg} \mathrm{CaO} / \mathrm{ha} /$ year & 0 & 175 \\
\hline Manganese sulphate & $\mathrm{kg} / \mathrm{ha} /$ year & 0 & 5.6 \\
\hline Total pesticides (unspecified) & $\mathrm{kg} / \mathrm{ha} /$ year & 1.03 & 1.15 \\
\hline Total diesel consumption & $\mathrm{kg} / \mathrm{ha} /$ year & 230 & 0.74 \\
\hline Direct $\mathrm{N}_{2} \mathrm{O}$ emissions from soil ${ }^{b}$ & kg N/ha/year & 0.66 & 0.15 \\
\hline $\mathrm{NO}_{3}{ }^{-}$leaching ${ }^{\mathrm{b}}$ & kg N/ha/year & 63.30 & 50.03 \\
\hline Indirect $\mathrm{N}_{2} \mathrm{O}$ from $\mathrm{NO}_{3}^{-}$leaching & $\mathrm{kg} \mathrm{N} / \mathrm{ha} /$ year & 0.48 & 0.38 \\
\hline Road transport (farm to storage) & $\mathrm{km}$ & 50 & 50 \\
\hline Road transport (storage to plant) & $\mathrm{km}$ & 50 & 50 \\
\hline Diesel (Loading \& Offloading) & $\mathrm{kg} / \mathrm{kg}$ feedstock & $7.68 \mathrm{E}-04$ & $7.68 \mathrm{E}-04$ \\
\hline
\end{tabular}


Accepted manuscript of article accepted for publication in Biofuels, Bioproducts and Biorefining

1 Table 5. Weighted average (and standard deviation) grain yield outputs and total annual

2 collectable straw in catchment area based on STAMINA-winter wheat

\begin{tabular}{cccc}
\hline & Baseline Climate & Medium Emission & High Emission \\
& & scenario & scenario \\
Wheat grain yield & $7.94(0.39)$ & $8.54(0.12)$ & $8.76(0.11)$ \\
(t/ha 14.5\% moisture) & & & \\
Total collectable straw & 623.37 & 670.48 & 687.80 \\
(kt/year 14.5\% moisture) & & & \\
\hline
\end{tabular}

3

4

5

6

7

8

9

10

11

12

13

14 
Accepted manuscript of article accepted for publication in Biofuels, Bioproducts and Biorefining

1 Table 6. Simulated Miscanthus yield (and standard deviation) on selected loamy fine sand

2 soils

\begin{tabular}{cccc}
\hline & Baseline Climate & Medium Emission & High Emission \\
& & scenario & scenario \\
\hline Miscanthus yield & $13.76(0.35)$ & $18.43(0.42)$ & $19.71(0.67)$ \\
(t/ha 14.5\% moisture) & & & \\
\hline
\end{tabular}

3

4

5

6

7

8

9

10

11

12

13

14

15

16

17 
Accepted manuscript of article accepted for publication in Biofuels, Bioproducts and Biorefining

1 Table 7. $\mathrm{NO}_{3}{ }^{-}$Leaching and $\mathrm{N}_{2} \mathrm{O}$ emissions (and standard deviation) of SPBC and MPBC scenarios

SPBC

MPBC

\begin{tabular}{ccc}
\hline $\mathrm{NO}_{3}{ }^{-}$Leaching (kg N/ha/year) & $64.47(7.25)$ & $57.41(6.87)$ \\
\hline Direct $\mathbf{N}_{\mathbf{2}} \mathbf{O}(\mathrm{kg} \mathrm{N} / \mathrm{ha} /$ year) & $0.66(0.18)$ & $0.62(0.17)$ \\
\hline Indirect $\mathbf{N}_{\mathbf{2}} \mathrm{O}(\mathrm{kg} \mathrm{N} / \mathrm{ha} /$ year) & $0.48(0.05)$ & $0.43(0.05)$ \\
\hline Total $\mathbf{N}_{\mathbf{2}} \mathrm{O}(\mathrm{kg} \mathrm{N} / \mathrm{ha} /$ year) & 1.14 & 1.05
\end{tabular}

2 